\title{
Assessment on the Performance of a Rainwater Harvesting System
}

\author{
Azzlia Mohd Unaini ${ }^{1}$, Muhammad Rizal Razali ${ }^{2}$, Thamer Ahmed Mohammed Ali ${ }^{1,3}$, \\ Aidi Hizami Alias ${ }^{1}$, Ernaleza Mahsum ${ }^{1}$ \\ ${ }^{1}$ Department of Civil Engineering, Faculty of Engineering, University Putra Malaysia, Selangor, Malaysia \\ ${ }^{2}$ Corporate Planning Division, National Hydraulic Institute of Malaysia, Selangor, Malaysia \\ ${ }^{3}$ Department of Civil Engineering, College of Engineering, University of Baghdad, Baghdad, Iraq
}

Email address:

azzlia@upm.edu.my (A. M. Unaini),mrizal@nahrim.gov.my (M. R. Razali), thamer@gmail.com (T. A. M. Ali), aidi.hizami@gmail.com (A. H. Alias)

\section{To cite this article:}

Azzlia Mohd Unaini, Muhammad Rizal Razali, Thamer Ahmed Mohammed Ali, Aidi Hizami Alias, Ernaleza Mahsum. Assessment on the Performance of a Rainwater Harvesting System. Science Research. Vol. 5, No. 3, 2017, pp. 36-43. doi: 10.11648/j.sr.20170503.13

Received: April 1, 2017; Accepted: July 20, 2017; Published: August 7, 2017

\begin{abstract}
The rainwater harvesting system is an alternative way to meet domestic water demand. At the same time, it can also help in reducing run-off, especially in urban areas. In this study, a rainwater harvesting system, which located at the Faculty of Engineering, was taken as a case study. Indicators that measure the performance of the rainwater harvesting system have been developed. One such indicators are reliability, which is dependent on the rainfall and water consumption patterns, tank size and effective roof area. Flow meter and rain gauge used to measure the volume of harvested rainwater and collect the rainfall depth data respectively. In this study also, a model is developed to predict the volume of rainwater harvesting with respect to the rainfall depth with a particular roof catchment. It demonstrates good fits with $\mathrm{R}^{2}=0.952$. The reliability of rainwater harvesting using existing tank $4.08 \mathrm{~m}^{3}$ is $60.8 \%, 66.5 \%, 67.7 \%$ and $98.2 \%$ for Consumption 1 (flushing toilets, gardening and washing vehicle), Consumption 2 (flushing toilets and gardening), Consumption 3 (gardening and washing vehicle) and Consumption 4 (flushing toilets and washing vehicle) respectively. The run-off coefficient for the selected roof is found to be 0.92 .
\end{abstract}

Keywords: Rainwater Harvesting System, Reliability, Rainfall Depth, Run-off Coefficient

\section{Introduction}

Water is an important and fundamental essence of living. The most part of the earth surface i.e. about $71 \%$ is covered by water. Out of total volume of water available on the surface of the earth $97 \%$ is saline water, $2 \%$ water is in the form of ice and glaciers and only $1 \%$ is fresh and potable water [12] [13]. In general, the major usage of fresh water is for agricultural activities with $67 \%$, followed by household (9\%), water supply (8\%), electricity and gas (7\%), manufacturing (4\%), mining (2\%) and other activities $(3 \%)$ [8]. This demand for fresh water is continuously increasing from year to year. Data from SPAN shows that the total water consumption in Malaysia had increased by $2 \%$ from 2010 to 2011, an increment from 5,602 MLD (domestic) and 3,370 MLD (non-domestic) in 2010 to 5,695 MLD (domestic) and
3,469 MLD (non-domestic) in 2011. The Domestic Water Consumption Study by Federation of Malaysian Consumers Associations (FOMCA) and the Energy, Green Technology and Water Ministry (2007-2010) had found that the rate of water wastage in Malaysia was the highest as compared with other countries in the region. Malaysian household used an average of 226 liters per capita per day (LCD); a very high figure as compared to the water usage in neighboring countries such as Singapore (155 LCD) and Thailand (90 LCD) (NST, $8^{\text {th }}$ Oct 2010). Domestic water usage can be characterized into indoor water usage (bathing, toilet flushing, cooking, tap etc.) and outdoor water usage (lawn watering, swimming pool, car washing etc.). Thus, authorities and households are currently looking at decentralized water supply system, including on the usage of rainwater harvesting system (RWHS) [7] [15]. 
Water harvesting is the activity of direct collection of rainwater, which can be stored for direct use or recharged into the groundwater. Water harvesting is the collection of runoff for productive purposes and maybe one of the best methods available to recovering the natural hydrologic cycle and enabling urban development to become sustainable [11] [12] [13] [15]. Apart from that, the changing rainfall pattern due to global warming can cause natural disaster, especially flash flood. For example, Malaysian Meteorological Department (2009) had found that the rainfall quantity recorded in some parts of Malaysia had shown a marked increase from 2004. This can cause extensive damage to properties and inconveniencing the resident of the city. Rainwater harvesting system can partly assist in solving this problem by regulating flow at the upstream area through local on-site detention. This will help in controlling the flash flood, as well as other natural disaster related to heavy rainfall.

\section{Problem Statement}

Rainwater harvesting is a potential and sustainable alternative water sources to solve water shortage problems, particularly in developing countries. Rainwater quantity can be predicted through modeling as has been demonstrated by several researchers in optimizing storage size [15]. Studies have shown that the household water demand is continuously increasing. With the current rapid rate of urbanization, it can be expected that this demand will continuously increase in the future. However, the current water supply is limited and finite in nature. For example, in 1998, dry season due to
El-Nino phenomenon had left about 1.8 million residents in the Klang Valley region with insufficient quantity of water [14]. Thus, RWHS should be able to partly assist in ensuring continuous supply of water to these residents. However, there is a possibility that the installed RWHS in some of the area is not adequate in collecting and supplying water to non-potable water usage in the area. This study attempt to study the performance of this RWHS system, by using RWHS installed in the Faculty of Engineering UPM as a case study.

\section{Study Area and Basic Data}

The study is focusing on the rainwater harvesting system installed in the Faculty of Engineering, Universiti Putra Malaysia (UPM), through assessment of rainwater collection and non-potable water consumption. In this study, the data of rainwater harvesting, water demand and rainfall was collected from April 29, 2013 until May 29, 2013. The volume of rainwater harvesting was monitored using Sensus Flow Meter that linked to the rainwater harvesting system. The rainfall depth data were collected using HOBO rain gauge equipment that has been installed at the rooftop of Administration Building, Faculty of Engineering, UPM.

As for the water demand, the demand depends on several factors such as number of people in the building, average consumption per person and the range of usage (drinking, toilet, laundry, toilet, lawn watering etc.). Table 1 shows the amount of water usage for different appliances and outdoor application which was adopted from Rainwater Harvesting Guidebook [2].

Table 1. Rainwater Demand for Domestic Application (DID, 2009).

\begin{tabular}{llll}
\hline Use (Appliance) & Type & Average Consumption & Average Total Rainwater Demand \\
\hline 1) Indoor Toilet & Single Flush & 9 liters per flush & 120 liters per day \\
& Dual flush & 6 or 3 liters per flush & 40 liters per day \\
& Twin Tub (semi-auto) & & 40 liters per wash \\
Washing Machine & Front Loading & 80 liters per wash \\
& Top Loading & & 170 liters per wash \\
& - & & $20-50$ liters per load \\
Dishwasher & - & $10-20$ liters per minute & 150 liters per day \\
General Cleaning & & $10-20$ liters per minute & 1000 liters per hour \\
2) Outdoor Sprinkler or Handheld Hose & & 4 liters per hour \\
Drip System & & 20 liters per minute & 200 liters per wash \\
Hosing Paths/Driveways & & $10-20$ liters per minute & $100-300$ liters per wash \\
Washing car with a running hose & &
\end{tabular}

\section{Methodology}

\subsection{Modification and Repairing of the Rainwater Harvesting (RWH) System at Faculty of Engineering, UPM}

The rainwater harvesting system used composed of six basic components: roof catchment, gutters and downspout, leaf screen and roof-washers, storage tanks, conveying and water treatment [11] [12] [13] [15]. To determine the accurate reliability of rainwater, minor modification has been done to the existing system. The rainwater harvesting system at the
Faculty of Engineering has been modified by installing a flow meter at the downpipe end. It is an instrument used to measure volumetric of water that flow through the device. The device installed in the system to ensure the capacity of the rainwater-harvested data collected is accurate and the rainwater, which is exceeding capacity of the tank, can be measured. The downpipe has been replaced to a new pipe to eliminate the leaking problem. It is due to the drift aspect and low quality of material has been used before.

\subsection{Non-potable Water Demand at the Faculty of Engineering}

In this study, data of the water demand in the faculty has 
been gathered, specifically the non-potable water demand. There are three main activities that has been identified which are toilet flushing, lawn watering and car washing. The data of the water demand for flushing toilet was taken from the previous study [9]. Survey had been conducted for toilet usage in Block B, Faculty of Engineering, while the schedule of watering the garden and washing faculty's vehicles taken from the Development Division, Faculty of Engineering. Table 2 shows the non-potable water demand at the Faculty of Engineering, UPM.

Table 2. Non-Potable Water Demand at the Faculty of Engineering.

\begin{tabular}{lll}
\hline Use (Consumption) & Unit & Average Water Use \\
\hline Single Flush Toilet & 16 people & $12 \mathrm{l} / \mathrm{flush}$ \\
Gardening & 30 minutes & $20 \mathrm{l} / \mathrm{minute}$ \\
Washing Vehicles (20 minutes/car once a week) & 3 vehicles & $20 \mathrm{l} / \mathrm{minute}$ \\
\hline
\end{tabular}

The non-potable water demand at the Faculty of Engineering were classified into four types of consumption. The activities in Consumption 1 consists of toilet flush, gardening and car washing. Consumption 2 consists of flushing toilets and gardening. For Consumption 3, it consists of gardening and car washing while for Consumption 4, the activities are toilet flushing and car washing. Therefore, the daily water demand can be calculated from Table 2. Previously [9], had recorded 1,9341 data of water consumption by staff and students from December 2010 to March 2011, where the author had found that the average usage of water for single flushing is 121 . The 121 per flush had been recorded by using flow meter that installed to the inlet of the cistern. The average user that used the toilet is 16 persons/day. The volume of water used for single flushing were measured at the same toilet to ensure that the data can be considered in this study [9]. Table 3 shows the actual volume consumed for each toilet.

Table 3. Volume of Water used for Single Flushing.

\begin{tabular}{ll}
\hline No. of Toilet & Volume of Water (Single Flushing), $\boldsymbol{l}$ \\
\hline Toilet 1 & 15.600 \\
Toilet 2 & 6.256 \\
Toilet 3 & 12.500 \\
Average & 11.452 \\
\hline
\end{tabular}

The volume of water consumption for toilet flushing differ from one toilet to another. This is because the physical condition of the cisterns were not in good condition, where one of the cisterns tends to flush out $100 \%$ water, while the others did not flush to the full capacity of the cistern. Therefore, the average volume is calculated and taken as the demand of flushing the toilet, which is $11.452 \mathrm{l}$. To cater for worst-case condition, the value of the average volume is round up to 121 . Cleaning landscape schedule at the Faculty of Engineering was obtained from The Development Division of the faculty. From the schedule, the time allocated for watering the garden was 30 minutes every morning. Apart from that, the Faculty also has three cars, where all the cars were sent to commercial car wash for cleaning purposes. By referring to the Rainwater Demand for Domestic Application [2] in Table 2, the average consumption is calculated as $20 \mathrm{l} /$ minute.

\subsection{Hydrological Data Collection}

Hydrological data required for this study is rainfall data.
The data taken from the Department of Irrigation and Drainage, Ampang District for the Sungai Kuyuh Total Station. Rainfall data at Sungai Kuyuh Total Station had been chosen because it is the nearest total station located at the Faculty of Engineering. There are 12 years' rainfall data recorded at the DID from February 2002 to 2013. Apart from that, the rainfall depth data also collected on site from 29 April to 29 May 2013. The data was collected using HOBO rain gauge device. The device was placed at the rooftop of the admin building, Faculty of Engineering. The data transferred to the computer by using data logger. The data is regularly transferred to ensure that the device is operating in a good condition. It is also considered as intermediate check to the device.

\section{Results and Discussion}

\subsection{Rainwater Harvesting Tank Size and the Reliability Based on Historical Rainfall Data}

The sizing of rainwater tank depends on rainfall amount and variability, daily rate consumption and type of roofing. The method for sizing a rainwater-harvesting tank in this section depends on the historical rainfall data that can gives estimation of the rainwater runoff collected from the selected roof. The average of monthly rainfall depth for the observation years were used in this analysis. The runoff coefficient was taken as 0.84 , similar to the previous study [6] [9] [11] [13]. The area of the chosen roof is $170 \mathrm{~m}^{3}$. The water demand was categorized into four consumptions. Each consumption has its own activities as shown in Table 4. The activities applied in the analysis based on the actual data. Similar to M. Y. Noorayuzlina [9], 16 people were used as an average of people using the toilet flush in a day. The gardening activity is expected to cover the area within the Phase 2 B Faculty of Engineering. Meanwhile for the washing vehicle, there are three units of faculty's vehicle. The monthly water demands can be calculate based on the actual demand tabulated in Table 4.

Table 5 shows that the 6 months' water demands were more than the rainwater collected. The comparison shows that the rainwater collected is not sufficient to accommodate the demand on June up to September. For Consumption 1, the tank size was assumed to be $60 \mathrm{~m}^{3}$ based on average rainfall depth occurred. The average of reliability for $60 \mathrm{~m}^{3}$ tank is $99.77 \%$. Table 6 shows the availability of rainwater after 
used as well as the shortage of rainwater in every month based on the average monthly rainfall depth from 2002 to 2013. For consumption 2, Table 5 an increase in the reliability as compared to Consumption 1, but still insufficient to accommodate $100 \%$ monthly usage of rainwater. Even though the monthly water available failed to accommodate the monthly demand in May to August with total shortage of $23.98 \mathrm{~m}^{3}$, the excess water from the previous month $\left(34.09 \mathrm{~m}^{3}\right)$ should be capable to accommodate the shortage of water during that period.

Table 4. Water Consumption.

\begin{tabular}{|c|c|c|c|c|c|c|}
\hline \multirow{2}{*}{ Use (Consumption) } & \multirow{2}{*}{ Unit } & \multirow{2}{*}{ Average Water Use } & \multicolumn{4}{|c|}{ Total Water Use (l/day) } \\
\hline & & & Consumption 1 & Consumption 2 & Consumption 3 & Consumption 4 \\
\hline Single Flush Toilet & 16 people & $12 \mathrm{l} /$ flush & 192 & 192 & - & 192 \\
\hline Gardening & 30 minutes & $20 \mathrm{l} /$ minute & 600 & 600 & 600 & - \\
\hline Washing Vehicles (20 $\mathrm{min} /$ car once a week) & 3 vehicles & $20 \mathrm{l} /$ minute & 171.43 & - & 171.43 & 171.43 \\
\hline Total & & & 963.43 & 792 & 771.43 & 363.43 \\
\hline
\end{tabular}

Table 5. Reliability of Rainwater Consumption.

\begin{tabular}{|c|c|c|c|c|c|c|c|c|c|c|}
\hline \multirow{2}{*}{$\begin{array}{l}\text { Month } \\
\text { Jan }\end{array}$} & \multirow{2}{*}{$\begin{array}{l}\text { Ave. Monthly Rainfall } \\
\text { Depth, (mm) (data } \\
\text { 2012-2013) } \\
203.45\end{array}$} & \multirow{2}{*}{$\begin{array}{l}\text { Average } \\
\text { Rainwater } \\
\text { Available, }\left(\mathbf{m}^{\mathbf{3}}\right) \\
29.05\end{array}$} & \multicolumn{2}{|c|}{$\begin{array}{l}\text { Water Demand, }\left(\mathrm{m}^{3}\right) \\
\text { Consumption } 1 / \% \\
\text { Reliability }\end{array}$} & \multicolumn{2}{|c|}{$\begin{array}{l}\text { Water Demand, }\left(\mathrm{m}^{3}\right) \\
\text { Consumption } 2 / \% \\
\text { Reliability }\end{array}$} & \multicolumn{2}{|c|}{$\begin{array}{l}\text { Water Demand, }\left(\mathrm{m}^{3}\right) \\
\text { Consumption } \mathbf{3} / \% \\
\text { Reliability }\end{array}$} & \multicolumn{2}{|c|}{$\begin{array}{l}\text { Water Demand, }\left(\mathrm{m}^{3}\right) \\
\text { Consumption } 4 / \% \\
\text { Reliability } \\
\end{array}$} \\
\hline & & & 29.87 & 97.3 & 24.55 & 100.0 & 23.91 & 100.0 & 11.27 & 100.0 \\
\hline Feb & 203.23 & 29.02 & 26.98 & 100.0 & 22.18 & 100.0 & 21.60 & 100.0 & 10.18 & 100.0 \\
\hline Mar & 220.96 & 31.55 & 29.87 & 100.0 & 24.55 & 100.0 & 23.91 & 100.0 & 11.27 & 100.0 \\
\hline Apr & 276.70 & 39.51 & 28.90 & 100.0 & 23.76 & 100.0 & 23.14 & 100.0 & 10.90 & 100.0 \\
\hline May & 150.81 & 21.54 & 29.87 & 72.1 & 24.55 & 87.7 & 23.91 & 90.1 & 11.27 & 100.0 \\
\hline July & 123.36 & 17.62 & 29.87 & 59.0 & 24.55 & 72.7 & 23.91 & 73.7 & 11.27 & 100.0 \\
\hline Aug & 151.26 & 21.60 & 29.87 & 72.3 & 24.55 & 88.0 & 23.91 & 90.3 & 11.27 & 100.0 \\
\hline Sept & 166.61 & 23.79 & 28.90 & 82.3 & 23.76 & 100.0 & 23.14 & 100.0 & 10.90 & 100.0 \\
\hline Oct & 236.02 & 33.70 & 29.87 & 100.0 & 24.55 & 100.0 & 23.91 & 100.0 & 11.27 & 100.0 \\
\hline Nov & 362.51 & 51.77 & 28.90 & 100.0 & 23.76 & 100.0 & 23.14 & 100.0 & 10.90 & 100.0 \\
\hline Dec & 215.56 & 30.78 & 29.87 & 100.0 & 24.55 & 100.0 & 23.91 & 100.0 & 11.27 & 100.0 \\
\hline
\end{tabular}

Table 6. $60 \mathrm{~m}^{3}$ of Rainwater Harvesting Tank Size.

\begin{tabular}{|c|c|c|c|c|c|c|c|}
\hline Month & $\begin{array}{l}\text { Average Monthly } \\
\text { Rainfall Depth, mm } \\
\text { (data 2002-2013) }\end{array}$ & $\begin{array}{l}\text { Maximum } \\
\text { Rainwater } \\
\text { Available, } \mathbf{m}^{\mathbf{3}} \\
\end{array}$ & $\begin{array}{l}\text { Water Demand, } \mathbf{m}^{3} \\
\text { (Consumption } 1 \text { ) }\end{array}$ & $\begin{array}{l}\text { Cumulative of } \\
\text { Available } \\
\text { Rainfall, } \mathbf{m}^{3} \\
\end{array}$ & $\begin{array}{l}\text { Rainfall Water } \\
\text { Stored in the } 60 \\
\mathbf{m}^{3} \text { Tank }\end{array}$ & $\begin{array}{l}\text { Rainfall Water } \\
\text { Left in the } 60 \mathrm{~m}^{3} \\
\text { Tank }\end{array}$ & $\begin{array}{l}\text { Reliability, } \\
\%\end{array}$ \\
\hline Jan & 203.45 & 29.05 & 29.87 & 29.05 & 29.05 & $\underline{0}$ & 97.25 \\
\hline Feb & 203.23 & 29.02 & 26.98 & 29.02 & 29.02 & 2.04 & 100.00 \\
\hline Mar & 220.96 & 31.55 & 29.87 & 33.59 & 33.59 & 3.72 & 100.00 \\
\hline Apr & 276.70 & 39.51 & 28.90 & 43.23 & 43.23 & 14.33 & 100.00 \\
\hline May & 150.81 & 21.54 & 29.87 & 35.87 & 35.87 & 6.00 & 100.00 \\
\hline July & 123.36 & 17.62 & 29.87 & 17.62 & 17.62 & $\underline{0}$ & 100.00 \\
\hline Aug & 151.26 & 21.60 & 29.87 & 21.60 & 21.60 & $\underline{0}$ & 100.00 \\
\hline Sept & 166.61 & 23.79 & 28.90 & 23.79 & 23.79 & $\underline{0}$ & 100.00 \\
\hline Oct & 236.02 & 33.70 & 29.87 & 33.70 & 33.70 & 3.83 & 100.00 \\
\hline Nov & 362.51 & 51.77 & 28.90 & 55.60 & 55.60 & 26.70 & 100.00 \\
\hline Dec & 215.56 & 30.78 & 29.87 & 57.48 & 57.48 & 27.61 & 100.00 \\
\hline \multicolumn{4}{|c|}{ Average of Reliability for $60 \mathrm{~m}^{3}$ tank } & 99.77 & & & \\
\hline
\end{tabular}

To overcome the shortage problem, the optimum sizing of the tank must be identified [5] [11] [13]. The excess rainwater can be stored and used during dry period. By using $48 \mathrm{~m}^{3}$ tank, there will be no shortage occurred. Therefore, the optimum size of the tank recommended for consumption 2 is $48 \mathrm{~m}^{3}$. The minimum available water that left in the tank is $0.29 \mathrm{~m}^{3}$. The reliability in consumption 2 is $100 \%$ with $48 \mathrm{~m}^{3}$ size of tank. Consumption 3 consists of gardening and washing cars. To ensure than the rainwater is sufficient to accommodate the demands, $45 \mathrm{~m}^{3}$ of tank size is recommend as an optimum size and gives $100 \%$ reliability. Consumption 4 consists of flushing toilet and washing cars. The rainwater gives more than $100 \%$ reliability to all of the months. To ensure than the rainwater is sufficient to accommodate the demands, $13 \mathrm{~m}^{3}$ of tank size is recommend.5.2 The Analysis of the Actual Rainwater Data Collected

In this section, the actual of rainwater harvesting data were collected by using Sensus Flow Meter. The duration of data collection was from 29 April to 29 May 2013. During the period, there are 10 rainfall events. Table 7 shows the total of rainwater volume collected through $170-\mathrm{m}^{2}$ roof with the information of the rainfall event. The volume of rainwater harvested is ranging from $0.034 \mathrm{~m}^{3}$ to $9.498 \mathrm{~m}^{3}$. 
Table 7. Volume of Rainwater Harvesting in 1 Month Observation.

\begin{tabular}{llll}
\hline Rain Event & Date & Rainfall Depth, $\mathbf{~ m m}$ & ${\text { Volume, } \mathbf{m}^{\mathbf{3}}}$ \\
\hline 1 & 29-Apr-13 & 52.25 & 9.4980 \\
2 & 30-Apr-13 & 26.42 & 4.1585 \\
3 & 4-May-13 & 4.06 & 0.9315 \\
4 & 6-May-13 & 10.41 & 1.7460 \\
5 & 7-May-13 & 40.25 & 5.3710 \\
6 & 14-May-13 & 0.25 & 0.0340 \\
7 & 15-May-13 & 8.90 & 1.2360 \\
8 & 16-May-13 & 0.51 & 0.2400 \\
9 & 17-May-13 & 2.30 & 0.3310 \\
10 & 24-May-13 & 45.47 & 6.2710 \\
\hline
\end{tabular}

Throughout the observation, it was found that unstable reading occurred between the end of rainfall event on $7^{\text {th }}$ May to the next rainfall event which in $14^{\text {th }}$ May. During that period, there was no rainfall and the tank was empty. From 1 month of observation, the relationship between the volume of rainwater harvesting and rainfall depth is shown in Figure 1. Out of 10 data recorded, only eight data were used to plot the relationship graph. The two data were not considered because the data was not relevant due to the very small volume of rainwater recorded. Figure 1 shows that the relationship between volume and rainfall depth is directly proportional to each other. As the rainfall depth increase, the volume of rainwater harvesting is also increase. However, the graph shown not indicates a smooth graph. This might happened because of the error due to the equipment (flow meter and rain gauge) and environment condition. Therefore, a linear line that intercept to the origin was created to get the possible trend to signify the relationship between the two parameters.

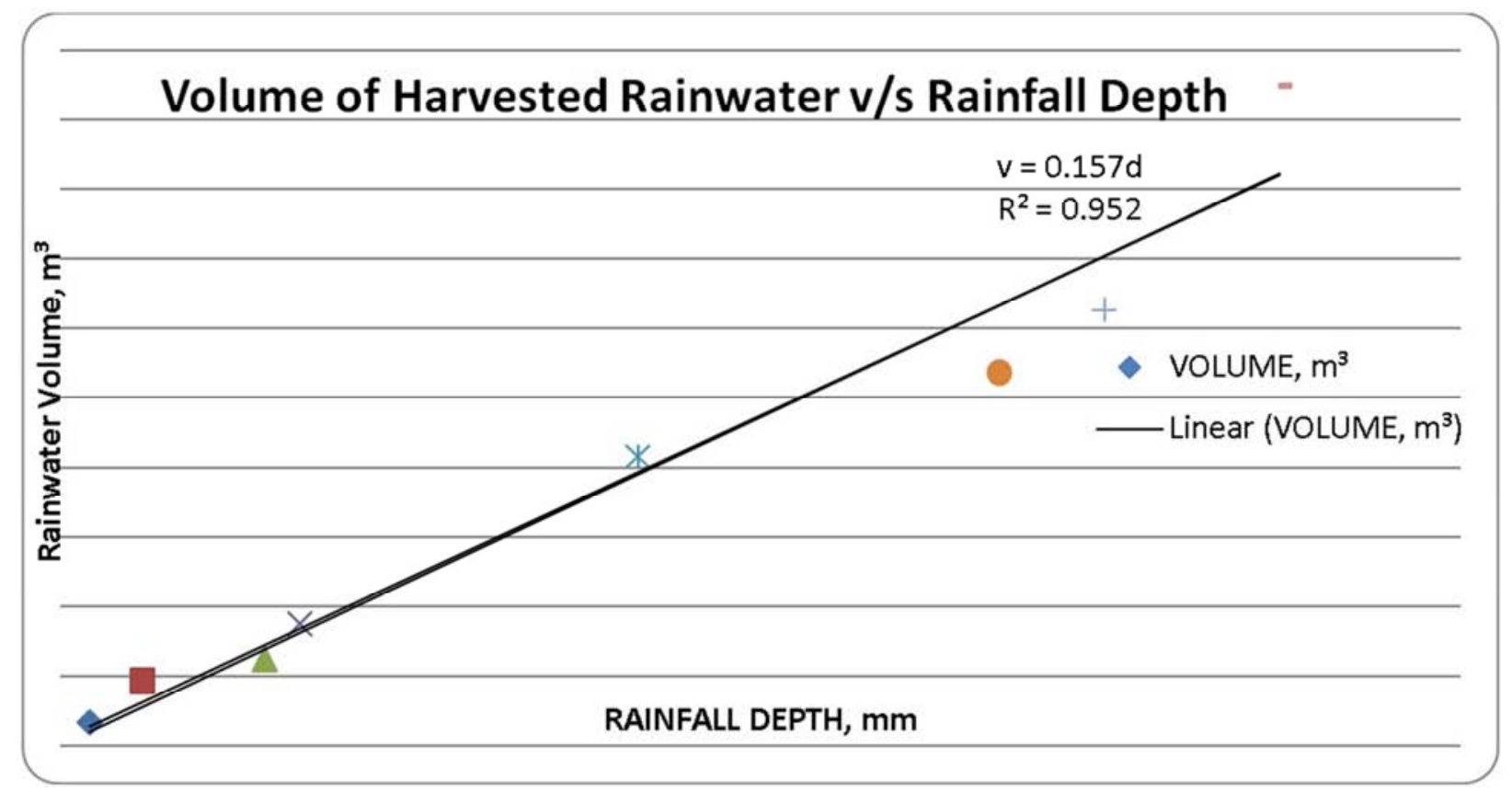

Figure 1. Relationships between Volume of Harvested Rainwater and Rainfall Depth for RWH System at Faculty of Engineering.

The linear relationship between the two parameters shows the high reliable result with $\mathrm{R}^{2}$ of 0.952 . Therefore, the relationship between volume of harvested rainwater and rainfall depth can be identified as below;

$$
\mathrm{V}=0.157 \mathrm{~d}
$$

Where,

$\mathrm{V}=$ Volume of Harvested Rainwater, $\mathrm{m}^{3}$

$\mathrm{d}=$ Rainfall Depth, $\mathrm{mm}$

\subsection{The Reliability of the Rainwater Harvesting Collected}

Table 8 indicate Average Reliability $60.8 \%$ the usage of rainwater for Consumption 1 with respect to the existing tank $\left(4.08 \mathrm{~m}^{3}\right)$. By using the same calculation, the Average Reliability for Consumption 2, 3, and 4 is $66.5 \%, 67.7 \%, 98.2 \%$ respectively. Based on the volume of rainwater collected from the 29th April to the 29th May 2013, it shows that the reliability of rainwater is less than $100 \%$ in 13 days for Consumption 1 , followed by 12 days for consumption 2 and 3 , and 1 day for consumption 4 . Thus, it indicates that with the existing rainwater harvesting tank $\left(4.08 \mathrm{~m}^{3}\right)$, the volume of harvested rainwater can only cater for activities in consumption 4. Resizing of the rainwater-harvesting tank is required to fulfill the consumption 1, 2, 3 and 4. Tables 9 indicates the average reliability $94.86 \%$ for the use of rainwater for Consumption 1 by resizing the tank to $13 \mathrm{~m}^{3}$ and $100 \%$ respectively for others Consumption. $100 \%$ of reliability 
can be reached by using $13 \mathrm{~m}^{3}$ rainwater harvesting tank for all consumption group except Consumption 1. However, the percentage of reliability on $22^{\text {nd }}$ and 23 May is less than $100 \%$ for consumption 1 , which is due to no rainfall occurred for six successive days. The historical rainfall analysis also showed that the rainfall continuously decreasing starting from April to
June. Even though $13 \mathrm{~m}^{3}$ is the optimum size to fulfill all demand from Consumption 1 to Consumption 4, it requires certain budget in terms of resizing the existing tank from 4.08 $\mathrm{m}^{3}$ to $13 \mathrm{~m}^{3}$. Apart from that, certain budget is also required to install piping system to supply water from rainwater harvesting tank to the respected toilet.

Table 8. Reliability of Consumption 1 with $4.08 \mathrm{~m}^{3}$ Tank.

\begin{tabular}{|c|c|c|c|c|c|c|c|}
\hline Date & $\begin{array}{l}\text { Rainfall } \\
\text { Depth, mm }\end{array}$ & Volume, $\left(\mathbf{m}^{3}\right)$ & $\begin{array}{l}\text { Cumulative Available } \\
\text { Rainwater }\left(\mathbf{m}^{3}\right)\end{array}$ & $\begin{array}{l}\text { Maximum Rainwater } \\
\text { Stored in } 4.08 \mathrm{~m}^{3} \text { Tank }\end{array}$ & $\begin{array}{l}\text { Consumptio } \\
\mathrm{n} 1\left(\mathrm{~m}^{3}\right)\end{array}$ & $\begin{array}{l}\text { Rainwater Left } \\
\text { in } 4.08 \mathrm{~m}^{3} \text { Tank }\end{array}$ & $\%$ Reliable \\
\hline 29-Apr & 52.25 & 9.50 & 9.50 & 4.08 & 0.96 & 3.12 & 100 \\
\hline 30-Apr & 24.75 & 4.16 & 7.28 & 4.08 & 0.96 & 3.12 & 100 \\
\hline 1-May & 0.00 & 0.00 & 3.12 & 3.12 & 0.96 & 2.16 & 100 \\
\hline 2-May & 0.00 & 0.00 & 2.16 & 2.16 & 0.96 & 1.20 & 100 \\
\hline 3-May & 0.00 & 0.00 & 1.20 & 1.20 & 0.96 & 0.24 & 100 \\
\hline 4-May & 2.00 & 0.93 & 1.17 & 1.17 & 0.96 & 0.21 & 100 \\
\hline 5-May & 0.00 & 0.00 & 0.21 & 0.21 & 0.96 & $\underline{0}$ & 22 \\
\hline 6-May & 10.25 & 1.75 & 1.75 & 1.75 & 0.96 & 0.79 & 100 \\
\hline 7-May & 40.25 & 5.37 & 6.16 & 4.08 & 0.96 & 3.12 & 100 \\
\hline 8-May & 0.00 & 0.00 & 3.12 & 3.12 & 0.96 & 2.16 & 100 \\
\hline 9-May & 0.00 & 0.00 & 2.16 & 2.16 & 0.96 & 1.20 & 100 \\
\hline 10-May & 0.00 & 0.00 & 1.20 & 1.20 & 0.96 & 0.24 & 100 \\
\hline 11-May & 0.00 & 0.00 & 0.24 & 0.24 & 0.96 & $\underline{0}$ & $\underline{25}$ \\
\hline 12-May & 0.00 & 0.00 & 0.00 & 0.00 & 0.96 & $\underline{0}$ & $\underline{0}$ \\
\hline 13-May & 0.00 & 0.00 & 0.00 & 0.00 & 0.96 & $\underline{0}$ & $\underline{0}$ \\
\hline 14-May & 0.25 & 0.03 & 0.03 & 0.03 & 0.96 & $\underline{0}$ & $\underline{3}$ \\
\hline 15-May & 8.75 & 1.24 & 1.24 & 1.24 & 0.96 & 0.28 & 100 \\
\hline 16-May & 0.50 & 0.24 & 0.52 & 0.52 & 0.96 & $\underline{0}$ & $\underline{54}$ \\
\hline 17-May & 1.25 & 0.33 & 0.33 & 0.33 & 0.96 & $\underline{0}$ & $\underline{34}$ \\
\hline 18-May & 0.00 & 0.00 & 0.00 & 0.00 & 0.96 & $\underline{0}$ & $\underline{0}$ \\
\hline 19-May & 0.00 & 0.00 & 0.79 & 0.79 & 0.96 & $\underline{0}$ & $\underline{82}$ \\
\hline 20-May & 0.00 & 0.00 & 0.00 & 0.00 & 0.96 & $\underline{0}$ & $\underline{0}$ \\
\hline 21-May & 0.00 & 0.00 & 0.00 & 0.00 & 0.96 & $\underline{0}$ & $\underline{0}$ \\
\hline 22-May & 0.00 & 0.00 & 0.39 & 0.39 & 0.96 & $\underline{0}$ & $\underline{41}$ \\
\hline 23-May & 0.00 & 0.00 & 0.00 & 0.00 & 0.96 & $\underline{0}$ & $\underline{0}$ \\
\hline 24-May & 44.75 & 6.27 & 6.27 & 4.08 & 0.96 & 3.12 & 100 \\
\hline 25-May & 0.00 & 0.00 & 3.12 & 3.12 & 0.96 & 2.16 & 100 \\
\hline 26-May & 0.00 & 0.00 & 2.16 & 2.16 & 0.96 & 1.20 & 100 \\
\hline 27-May & 0.00 & 0.00 & 1.20 & 1.20 & 0.96 & 0.24 & 100 \\
\hline 28-May & 0.00 & 0.00 & 0.24 & 0.24 & 0.96 & $\underline{0}$ & $\underline{25}$ \\
\hline 29-May & 0.00 & 0.00 & 0.00 & 0.00 & 0.96 & $\underline{0}$ & $\underline{0}$ \\
\hline \multicolumn{4}{|c|}{ AVERAGE RELIABILTY FOR $4.08 \mathrm{~m}^{3}$ TANK } & $60.8 \%$ & & & \\
\hline
\end{tabular}

Table 9. Reliability of Consumption 1 with 13- $m^{3}$ Tank.

\begin{tabular}{|c|c|c|c|c|c|c|c|}
\hline Date & $\begin{array}{l}\text { Rainfall } \\
\text { Depth, mm }\end{array}$ & $\begin{array}{l}\text { Volume } \\
\left(\mathrm{m}^{3}\right)\end{array}$ & $\begin{array}{l}\text { Cumulative Available } \\
\text { Rainwater }\left(\mathbf{m}^{3}\right)\end{array}$ & $\begin{array}{l}\text { Maximum Rainwater } \\
\text { Stored in } 13 \mathrm{~m}^{3} \text { Tank }\end{array}$ & $\begin{array}{l}\text { Consumpti } \\
\text { on } 1\left(\mathrm{~m}^{3}\right) \\
\end{array}$ & $\begin{array}{l}\text { Rainwater Left } \\
\text { in } 13 \mathrm{~m}^{3} \text { Tank }\end{array}$ & \% Reliable \\
\hline 29-Apr & 52.25 & 9.50 & 9.50 & 9.50 & 0.96 & 8.53 & 100 \\
\hline 30-Apr & 24.75 & 4.16 & 12.69 & 12.69 & 0.96 & 11.73 & 100 \\
\hline 1-May & 0.00 & 0.00 & 11.73 & 11.73 & 0.96 & 10.77 & 100 \\
\hline 2-May & 0.00 & 0.00 & 10.77 & 10.77 & 0.96 & 9.80 & 100 \\
\hline 3-May & 0.00 & 0.00 & 9.80 & 9.80 & 0.96 & 8.84 & 100 \\
\hline 4-May & 2.00 & 0.93 & 9.77 & 9.77 & 0.96 & 8.81 & 100 \\
\hline 6-May & 10.25 & 1.75 & 9.59 & 9.59 & 0.96 & 8.63 & 100 \\
\hline 7-May & 40.25 & 5.37 & 14.00 & 13.00 & 0.96 & 12.04 & 100 \\
\hline 8-May & 0.00 & 0.00 & 12.04 & 12.04 & 0.96 & 11.07 & 100 \\
\hline 9-May & 0.00 & 0.00 & 11.07 & 11.07 & 0.96 & 10.11 & 100 \\
\hline 10-May & 0.00 & 0.00 & 10.11 & 10.11 & 0.96 & 9.15 & 100 \\
\hline 11-May & 0.00 & 0.00 & 9.15 & 9.15 & 0.96 & 8.18 & 100 \\
\hline 12-May & 0.00 & 0.00 & 8.18 & 8.18 & 0.96 & 7.22 & 100 \\
\hline 14-May & 0.25 & 0.03 & 6.29 & 6.29 & 0.96 & 5.33 & 100 \\
\hline 15-May & 8.75 & 1.24 & 6.56 & 6.56 & 0.96 & 5.60 & 100 \\
\hline
\end{tabular}




\begin{tabular}{|c|c|c|c|c|c|c|c|}
\hline Date & $\begin{array}{l}\text { Rainfall } \\
\text { Depth, mm }\end{array}$ & $\begin{array}{l}\text { Volume } \\
\left(\mathrm{m}^{3}\right)\end{array}$ & $\begin{array}{l}\text { Cumulative Available } \\
\text { Rainwater }\left(\mathbf{m}^{3}\right)\end{array}$ & $\begin{array}{l}\text { Maximum Rainwater } \\
\text { Stored in } 13 \mathrm{~m}^{3} \text { Tank }\end{array}$ & $\begin{array}{l}\text { Consumpti } \\
\text { on } 1\left(\mathrm{~m}^{3}\right)\end{array}$ & $\begin{array}{l}\text { Rainwater Left } \\
\text { in } 13 \mathrm{~m}^{3} \text { Tank }\end{array}$ & \% Reliable \\
\hline 16-May & 0.50 & 0.24 & 5.84 & 5.84 & 0.96 & 4.88 & 100 \\
\hline 17-May & 1.25 & 0.33 & 5.21 & 5.21 & 0.96 & 4.24 & 100 \\
\hline 18-May & 0.00 & 0.00 & 4.24 & 4.24 & 0.96 & 3.28 & 100 \\
\hline 19-May & 0.00 & 0.00 & 3.28 & 3.28 & 0.96 & 2.32 & 100 \\
\hline 20-May & 0.00 & 0.00 & 2.32 & 2.32 & 0.96 & 1.35 & 100 \\
\hline 21-May & 0.00 & 0.00 & 1.35 & 1.35 & 0.96 & 0.39 & 100 \\
\hline 23-May & 0.00 & 0.00 & 0.00 & 0.00 & 0.96 & $\underline{0}$ & $\underline{0}$ \\
\hline 24-May & 44.75 & 6.27 & 6.27 & 6.27 & 0.96 & 5.31 & 100 \\
\hline 25-May & 0.00 & 0.00 & 5.31 & 5.31 & 0.96 & 4.34 & 100 \\
\hline 26-May & 0.00 & 0.00 & 4.34 & 4.34 & 0.96 & 3.38 & 100 \\
\hline 27-May & 0.00 & 0.00 & 3.38 & 3.38 & 0.96 & 2.42 & 100 \\
\hline 28-May & 0.00 & 0.00 & 2.42 & 2.42 & 0.96 & 1.45 & 100 \\
\hline 29-May & 0.00 & 0.00 & 1.45 & 1.45 & 0.96 & 0.49 & 100 \\
\hline
\end{tabular}

\section{Conclusions}

Based on the result obtained and discussions in the present study, the following conclusions were made;

1) The required size of the rainwater harvesting varies depending on the consumption needs. For average monthly rainfall from historical data, it requires $48 \mathrm{~m}^{3}$ for consumption $2,45 \mathrm{~m}^{3}$ for consumption 3 , whereby for consumption 4 , it requires $13 \mathrm{~m}^{3}$ with $100 \%$ reliability. There is no recommended tank size to cater the demand for consumption 1 due to less rainfall intensity.

2) The coefficient of the rainfall depth obtained is 0.157 .

3) The reliability of rainwater harvesting system using existing tank of $4.08 \mathrm{~m}^{3}$ is $60.8 \%, 66.5 \%, 67.7 \%$ and $98.2 \%$ for Consumption 1, 2, 3 and 4 respectively.

4) The optimum size of rainwater harvesting tank for daily rainfall is $13 \mathrm{~m}^{3}$. The percent reliability for consumption 2, 3 and 4 is $100 \%$. The percent reliability for consumption 1 is $94.86 \%$.

5) The runoff coefficient of the catchment roof is 0.92

\section{Recommendations}

1) From the results obtained, the followings are therefore recommended;

2) Rainwater harvesting should be seen as a viable and reliable water supply option with abundant rainfall potentials.

3) Instead of individual usage, community participatory programed should be encourage in rainwater harvesting to make it more economical and affordable.

4) Specific regulations are imperative for guiding, restricting, and enforcing the adoption and attainment of the targeted technology potential. These should be recognizable at national level.

5) To promote urban water harvesting, policies should include a mix of incentives and penalties, and that such policy initiatives should be strengthened further through legislation.

\section{References}

[1] Aaron, L., Kirsten, S., \& Dave, R. A guidebook of resources and considerations for rainwater catchment, roof gardens and solar power, compiled and written by ingrid severson with excerpts from tapping the potential of urban rooftops.

[2] Department of Irrigation and Drainage Malaysia. (2009) Rainwater harvesting, guidebook planning and design.

[3] Department of Irrigation and Drainage Malaysia. (2012) urban stormwater management manual for Malaysia, MSMA $2^{\text {nd }}$ Edition. Kuala Lumpur: DID Malaysia.

[4] Dixon A., Butler D., Fewkes A. (1999). Water saving potential of domestic water reuse systems using greywater and rainwater in combination, Water Science and Technology, 39 (5), 25-32.

[5] Fewkes, A. (1999). The use of rainwater for WC flushing: The field-testing of a collection system. Building and Environment, 34, 765-772.

[6] Hwa, N. W. (2009). Reliability and assessment of rainwater harvesting system at the Faculty of Engineering, PhD Thesis, Faculty of Engineering, Universiti Putra Malaysia, Malaysia.

[7] Manoj, K. J., \& Nishant, S. (2015). Evaluating Rainwater Harvesting System for School Buildings. American Journal of Envoronment Sciences, Vol. 11 (4), p. p. 256-261.

[8] Micheal, V., \& Stuart, P. (2004). Water accounting in Australia, London Group Meeting, Denmark, Australian Bureau of Statistic.

[9] Noorayuzlina, M. Y. (2011). Study on reliability of rainwater harvesting system. PhD Thesis, Faculty of Engineering, Universiti Putra Malaysia, Malaysia.

[10] Numerical Weather Prediction Development Section, Technical Development Division, Malaysian Meteorological Department, \& Ministry of Science, Technology and Innovation. (2009). Climate change scenarios for Malaysia 2001-2099, Scientific Report. Unit Percetakan, Jabatan Meteorologi Malaysia.

[11] Pawar, C. B., Patil, S. S., \& Pawar, R. P. (2014). A Case Study of Rooftop Rainwater Harvesting of Renavi Village in Sangli District of Western Maharashtra: New Approach of Watershed Development in India. African Journal of Agricultural Research, Vol. 9 (25), p. p. 1941-1947. 
[12] Raj Kamal, B. (2016). Domestic Rainwater Harvesting- A Review. International Journal of Engineering Technology Science and Research, Vol. 3 (5), p. p. 193-199.

[13] Shittu, O. I., Okareh, O. T., \& Coker, A. O. (2015). Development of Rainwater Harvesting Technology for Securing Domestic Water Supply in Ibadan, Nigeria. International Research Journal of Engineering Science, Technology and Innovation, Vol. 4 (1), p. p. 32-37.
[14] Syafiqa, A., \& Siti Nazahiyah, R. (2017), Rainwater Harvesting and Groundwater Potential as Alternatives Water Resources in Malaysia: A Review, Universiti Tun Hussein Onn Malaysia. MATEC Web of Conference 103, 04020.

[15] Tulinave, B. M., Han, M. Y., \& Zacharia, K. (2016). Strategy to Overcome Barriers of Rainwater Harvesting, Case Study Tanzania. Journal of Geoscience and Environment Protection, Vol. 4, p. p. 13-23. 